\title{
Translingual Practice and Transcultural Connections in Assia Djebar's La Femme sans sépulture
}

\author{
Malika BOUSSOUALIM \\ Ecole nationale Supérieure d'Informatique (Algiers, Algeria) \\ University of Algiers 2, English Department \\ m_boussoualim@esi.dz
}

\begin{abstract}
La Femme sans sépulture is one of Djebar's recent publications which carries on with the author's self-proclaimed project of recreating an Arabo-Berber past in a French text. The recreation process is achieved through writing in French, which is invaded by Algerian women's oral voices. In this article, I will argue that French and Algerian oral languages - Arabic and Berber - mutually influence each other, allowing the emergence of new linguistic structures. This is evidenced in the text by the use of free indirect discourse which allows the oral to modify French while being modified by it. Relying on Suresh Canagarajah's studies on cross-language relations, the mutual relations between Algerian orality and French are interpreted as translingual practices aimed to promote transcultural communication.
\end{abstract}

Keywords: Assia Djebar, La Femme sans sépulture, translingual practices, transcultural communication.

\section{Introduction}

Assia Djebar, a prominent Algerian francophone writer, was born to a Berber father and an Arab mother in colonial Algeria, where the father, a school institutor, defied local mores by having his daughter enrolled in a French school. Her initiation into another language spoken by the father and exclusively used at school complicated the linguistic experience of the child, who had already been exposed to the Arabic of her mother and the Berber of the paternal grandmother. Growing up in such a multilingual environment, complicated by a complex colonial experience, increased the perspectives of the child, who grew up into a writer. Despite her multilingualism, the emergent writer could write only in one language - that of the colonizer "to inscribe" the experiences of the Arab-Berber 
ancestors and their descendants into a literary text characterized by switching between languages, Arabic, Berber, and French.

Djebar's multilingualism was a source of much disillusionment, which she described in her writings. In Writing in the Language of the Other, Djebar wrote, "My childhood, [...] was split [...] between two languages" (2003: 23). While she felt disillusioned for a long time about what her mother tongue was, Arabic or Berber, she found a comforting substitute in French. In Fantasia: An Algerian Cavalcade, Djebar expressed her disillusionment and comfort: "French is my 'stepmother tongue.' Which is my long-lost mother-tongue that left me standing and disappeared?" (1993: 214). The language of the colonizer - which she clearly recognized as a "stepmother tongue" - changed for her "into the father's language" (2003: 23), offering her "true welcome" (2003: 25). Yet, Djebar's relation to French was disillusioning too, as French was for her "a language imposed by rape as much as by love" (1993: 216).

Djebar's writings reflect her complex multilingual experience. Her literary production has a double aim, namely to recover the experiences of her ancestors, which she deliberately sought to "inscribe" in a French text. In an interview with Mildred Mortimer, Djebar explained her aims: "Je pense que le plus important pour moi est de ramener le passé malgré ou à travers l'écriture, 'mon' écriture de langue française. Je tente d'ancrer cette langue française dans l'oralité des femmes traditionnelles. Je l'enracine ainsi." (1988: 201) ["I think the key concern for me is to bring back the past despite or through writing, 'my' writing in French. I try to anchor the French language in the oral tradition of women. I root it as such." $]^{1}$

She achieved this double objective by listening carefully to the oral culture accounted for in the voices of women, then translating it into a literary French text; she wrote: "in the language known as the language of the other, I found myself possessed by the need to reminisce about an elsewhere, about a dead Arabo-Berber past, my own. [...] thus my Ariadne's thread became my ear. Yes, I heard Arabic and Berber [...]; I could truly hear them and thereby resuscitate them, those barbarians, in the French language" (2003: 25).

Djebar undertook the task of translating Algerian women's experiences and culture, which are traditionally oral, into a literary text written in a language characterized by movement between Algerian orality and French. Writing about Djebar's use of French as the language of her literary production has been treated by critics in different ways.

Many wrote about Djebar's choice to write in French and its ideological significance in a postcolonial Algeria where Arabic was imposed by the government as an official language instead of French, which had equally been imposed as the official language by the colonizer. For instance, in Which Qalam for Algeria?, Shaden M. Tageldin questions Djebar's choice to write in French

The translations from French are the author's throughout the article. 
and its motivations and complexities through a reading of Djebar's Fantasia as opposed to Dhākirat Al-Jasad written in Arabic by the Algerian female writer Ahlam Mustaghānimī. Through contrast between the two authors' linguistic choices and their effects on the restoration of Algerian women's occulted past, Tageldin doubts the ability of a French text to resuscitate the occulted female history that Djebar projected to recover (2009).

Other critics tried to read Djebar's novels with focus on their multilingualism. For instance, in The Multilingual Strategies of Postcolonial Literature: Assia Djebar's Algerian Palimpsest, Anne Donadey highlights the effects of Djebar's multilingual practices on the French language, allowing Djebar's text to turn into a palimpsest of languages. Donadey (2000: 34) argues that French is deterritorialized by Djebar's use of Arabic vocabulary and syntactic structures, but it is reterritorialized when made "more hospitable for arabophone readers". In France and the Maghreb: Performative Encounters, Mireille Rosello (2005) describes Djebar's use of language as writing "in-between languages" and praises her model of writing for its ability to achieve exchange despite violence.

\section{Theoretical framework}

While critics have focused on Djebar's choice of French as the language of her literary production or her use of French as reflective of multilingual practices, in this paper, I propose to read Djebar's use of language in one of her novels, namely La Femme sans sépulture, as achieving translingual rather than multilingual relations. Through an in-depth analysis of Djebar's language, this paper is aimed to explore the transformations resulting from contact between Algerian orality and French, which, I will argue, are aspects of translingual practices. The latter rely on the mutual relation between languages aimed to promote exchange and communication between cultures.

Describing Djebar's movement between languages as an evidence of translingual rather than multilingual practices finds cues in Suresh Canagarajah distinction between the two terms. He writes, "[w]hile the term multilingual perceives the relationship between languages in an additive manner (i.e., combination of separate languages), translingual addresses the synergy, treating languages as always in contact and mutually influencing each other, with emergent meanings and grammars" (2013:41). Canagarajah explains that the linguistic transformations resulting from translingual practices involve exchange and negotiations between cultures (2017: 51).

An important negotiation strategy in Djebar's text is free indirect discourse (FID). According to Monika Fludernik, studies of FID need to consider linguistic and contextual issues. From a linguistic perspective, FID can be defined through 
comparison with direct and indirect discourse; Fludernik thus writes: "free indirect discourse preserves some of the expressive elements of direct discourse as well as its syntactic independence, but shares with indirect discourse the temporal and referential consonance with the quoting instance" (1993: 71). Fludernik also emphasizes that - in addition to the linguistic features - the study of FID needs to take into consideration "a number of macro-textual and interpretative aspects of the reading process $[\ldots]$ as for example the question of point of view, the narrative situation, mood or voice; [...]. Even 'simple' grammatical features, such as the use of tense in narrative" (1993: 6).

FID is an ideal strategy to achieve switching between languages. In fact, FID has already been recognized as a key strategy used by translingual writers. In Translingual Practice, Lydia H. Liu distinguishes FID as a western strategy, used by modern Chinese translingual writers to translate Chinese culture (1995: 103). In this paper, we will see that Djebar's translingual practices allow a mutual influence between languages, generating the modification of both French and Algerian orality, using FID as a negotiation strategy.

Djebar's translingual practices, which blur the boundaries between languages and consequently between cultures, reflect what Wolfgang Welsch describes as transculturality. For Welsch, transculturality stands against the old conception of cultures characterized by "ethnic foundation; social homogenization; and intercultural delimitation" (2009: 5) resulting in "exclusion and conflict" and the impossibility of communication between cultures (2009: 6). It sketches the relation between cultures as "one of entanglement, intermixing and commonness" (1999: 205), promoting "exchange and interaction" and supporting "coexistence rather than combat" (1999: 204).

In La Femme, women are empowered with voice to tell their experiences; the outcome is a French text invaded by Algerian women's oral voices. I will investigate the author's ways of translating Algerian women's experiences into French, her representational strategies and rhetorical devices as well as the effects of the contact between Algerian orality and French. I will argue that the translation process is achieved through translingual practices marked by a masterful use of FID, which allows French and Algerian oral languages - Arabic and Berber - to influence each other. This mutual influence generates new meanings, new syntactical, grammatical, and lexical structures, which are viable to promote transcultural relations.

La Femme depicts the recovery of the story of Zoulikha, a forgotten heroine of the Algerian War of Independence, who was tortured and killed by the French colonial army and whose body disappeared. This quest is underscored by the return of a narrator-author to her hometown, Césarée, where she meets the forgotten heroine's relatives and friends, who tell their recollections about the past in as much as they relate to the contemporary problems of Algeria. The quest 
to recover the forgotten is motivated by the need to illuminate the reasons of the reiteration of violence in postcolonial Algeria.

Structurally, the novel opens with a prelude and ends with an epilogue in addition to twelve chapters including four monologues. In the prelude, a first person nameless narrator fixes the setting, introduces the protagonists, and then eclipses from the scene to return in the epilogue where a direct link between colonial and contemporary violence in Algeria is established. Meanwhile, this first-person narrator-character relinquishes the narration to a third-person voice to join the characters of the story as a listener referred to with different pseudo names; the female guest 'l'invitée', visitor 'la visiteuse', the listener 'l'écouteuse', the foreigner 'l'étrangère', and foreigner not really foreigner 'l'étrangère pas tellemment étrangère'. This "listener" sometimes mixes her memories with the reminiscences of the other voices telling Zoulikha's story. Yet, most of the time, she prefers to listen and expand the echo of women's voices. In addition to the first-person voice of the prelude and epilogue and the third-person narration with variable focalization, Djebar uses for this restoration task the voice of dead Zoulikha, who tells in monologues, invented by the author, the missing part of the story.

The novel is a rich and complex instance of a multiple vocal story told by female focalizers. Voices of variable focalizers speak while being spoken about by a third-person voice, which shifts between internal and external focalization. Those focalizers assume the narration in turns throughout the novel. Actually, Djebar relies on the relatives of Zoulikha, her sister-in-law Zohra Oudai, and her two daughters, Hania and Mina. The two daughters have initially been very reluctant to speak about a violent past, but they grow keener to speak as they have gained deliverance of the burdening silent past, encouraged by their attentive patient "listener". Zohra Oudai, an old Berber peasant, seems highly disillusioned by an incurable pessimism about the present, characterized by widespread corruption, but she finds relief only through immersion in the past. Djebar equally relies on the skilled ex-foreseer of the future, who proves equally skilled at restoring the past, Lla Lbia, Zoulikha's friend.

Djebar uses a special narrative mode to allow the voices of narration to convey their memories about the past, which foresees the future. It consists of a gradual shift from an external focalization to an internal focalization narrative representing the thoughts and then the voices of character focalizers. So, narratives start to be mediated by the voice of an external focalizer, approximate to a third-person narrator. The latter gradually relinquishes her voice to allow the reader to have direct access to character focalizers' thoughts at a first stage, then to their oral speech.

The movement from the representation of thoughts to the assumption of voice by the character focalizer, marked sometimes in the text as "Voix de..." [Voice of ...] followed by the name of the focalizer, is generally achieved when the focalizer 
reaches a level of immersion in the past to relive it. At this level, the narrative is more oral than written discourse, free from the comments of the third-person narrator, except for very limited observations describing physical features about the intonation and the rhythm of voice or about the movements and gestures of the character focalizer.

The different voices speak in a complex mix of direct, indirect, and FID discourse. Used with third-person and first-person narratives, FID allows the swift shift between the voices of narration in this polyphonic novel relying on shifting points of view to recover and uncover the hidden. Structurally, FID allows the overlap between characters' and narrator's voices, between oral speech and written text, and between Algerian orality and French. Linguistically, FID allows Algerian orality to appropriate and modify French while being modified by it. Through FID as a negotiation strategy, Djebar's French is sufficiently modified, underscoring the author's will to overcome the limitations of restrictive monolingualism. Through FID, which allows the narrator-author to blend her voice with the voices of the women telling the story, Djebar creates a chance for her narrator-author, sometimes referred to as 'l'étrangère' ['the foreigner'] to overcome the exclusion and estrangement experienced after her return to her hometown to collect history. Djebar's narrative and linguistic strategies underscore her will to overcome the exclusion enforced by linguistic purity politics in postcolonial Algeria.

Using FID as a negotiation strategy, this novel treats languages as mutually influencing each other; therefore, we can find instances of French modified by contact with Algerian orality and instances of Algerian orality modified by French. FID is used to represent both thought and voice in the novel. We find instances of FID in narratives rendered in the third-person voice representing thought with internal and external focalization. We also find instances of FID in narratives rendered as oral voices, approximate to a first-person voice. These oral voices represent voices haunting the minds of character focalizers and voices of these same focalizers liberated by immersion in the past to assume the narration instead of the third-person voice. The latter gradually faints from the narrative but remains as an attentive patient "listener".

I will show that in La Femme translingual practices are suggested as viable means to create better chances of communication in a postcolonial Algeria fallen back into violence as a consequence of the repetition of colonial imperialist politics focusing on homogeneity and linguistic purity. This is evidenced by the link between colonial and contemporary violence in Algeria, ${ }^{2}$ where the language issue acquires prominence not only through the author's stylistic and representational choices but also through direct questioning by the narratorauthor and her informants.

2 The link between colonial and contemporary violence in La femme is explored by Michael F. O'Riley (2007). 
In a conversation between the narrator-author and the youngest daughter of Zoulikha, Mina, the two women of postcolonial Algeria celebrate the diversity of the Algerian identity and culture by offering a revision to a celebrated hymn. The latter was taught at the pre-independence Arabic schools referred to in the text as madersa. The hymn says:

Nous avons une seule langue, l'arabe Nous avons une seule foi, l'Islam Nous avons une seule terre, l'Algérie! (2002: 77)
We have only one language, Arabic We have one faith, Islam

We have only one land, Algeria!

To reverse this hymn, the two women sing:

\begin{tabular}{ll}
\hline $\begin{array}{l}\text { Nous avons trois langues, et le berbère } \\
\text { d'abord [...] }\end{array}$ & $\begin{array}{l}\text { We have three languages, and the } \\
\text { earliest is Berber [...] }\end{array}$ \\
$\begin{array}{l}\text { Nous avons trois amours : } \\
\text { Abraham, Jésus...et Mohammed! }\end{array}$ & $\begin{array}{l}\text { We have three venerated saints: } \\
\text { Abraham, Jesus ... and Mohammed! } \\
\text { [....] }\end{array}$ \\
$\begin{array}{ll}\text { Nous pourrions aussi évoquer nos } \\
\text { ancêtres illustres : }\end{array}$ & $\begin{array}{l}\text { We may also mention our illustrious } \\
\text { ancestors: }\end{array}$ \\
$\begin{array}{ll}\text { Jugurtha, trahi, est mort à Rome, loin } \\
\text { de sa terre; }\end{array}$ & $\begin{array}{l}\text { Jugurtha, betrayed, died in Rome, far } \\
\text { La Kahina, notre reine des Aurès, }\end{array}$ \\
$\begin{array}{l}\text { faincue, s'est tué auprès d'un puits } \\
\text { Abdelkader, expatrié, s'est éteint à }\end{array}$ & $\begin{array}{l}\text { The Kahina, our Queen of the Aurés } \\
\text { mountains, vanquished, killed near a }\end{array}$ \\
$\begin{array}{l}\text { Damas, auprès } \\
\text { d'Ibn Arbi! (Italics in the original) } \\
\text { (2002: 78) }\end{array}$ & $\begin{array}{l}\text { Abdelkader, an expatriate, died in } \\
\text { Damascus, nearby Ibn Arbi! }\end{array}$ \\
\hline
\end{tabular}

Against the hymn preaching homogeneity through Arabization, Islamization, and nationalization, which are the fundamental principles of the postcolonial policies in Algeria, the narrator-author and her friend celebrate cultural mixedness. Through the revision of the hymn of homogeneity, Djebar's text emphasizes the need to blur the boundaries between languages, religions, territories, and genders in order to overcome the reiteration of colonial violence. The novel attempts to challenge this violence in a text that also blurs the boundaries between past, present, and future through a retrospective representation of the present and the past to warn against the perpetuation of violence in the future.

In this paper, I focus on Djebar's use of language and her strategies to overcome linguistic boundaries. The close analysis of how the author deals with language in the novel can provide insight into the translingual transformations and the 
transcultural connections resulting from contact between Algerian orality and French. Through the close reading of selected passages from the novel, this paper elaborates on how French is modified by Algerian orality and how Algerian orality is modified by French, using FID representing thought and voice. The reading is focused on showing the potentialities of translingual practices to create transcultural connections.

\section{Analysis}

\section{FID and the representation of thought}

According to Fludernik (1993), one of the common uses of FID occurs in narratives rendered in the third-person omniscient voice to represent thought. The representation of thought occurs when the narrator enters the mind of the character and represents his or her thoughts verbatim. In the novel, not only does the narrator provide information through omniscient narration, but the characters speak for themselves in FID in internal focalization narratives, reflected through the consciousness of a character focalizer. In such narratives, a character's "deictic centre" prevails as the major narrative orientation point. The "deictic centre" is a term used by Ann Banfield to describe those aspects of an utterance that refer to and depend upon the situation in which an utterance is made. Banfield defines the "deictic system" as follows: "The deictic system is thus internally divided between those terms which represent the (personal) subject - I in speech, he, she, or a human they in the writing of the novel - and those which represent only a subjective centre - the deictic adverbials of time and place" (qtd in Fludernik 1993: 381). According to Fludernik, in omniscient narration, the most obvious markers of FID are shift of pronominal reference and shift in tense (1993: 107, 193), "syntactic deviations" with "claims to expressivity" (1993: 223), and pragmatic categories including question and exclamation marks, dashes and quotation marks.

For instance, in the second chapter of the novel entitled Où trouver le corps de ma mère? [Where Shall I Find My Mother's Body?], we find significant instances of FID representing the thoughts of Zoulikha's elder daughter, Hania, within an internal focalization narrative. The chapter starts with a third-person narrative rendered in indirect and direct speech representing a conversation between Zoulikha's daughters and their "visitor" collecting the story of their mother. Gradually, the third-person voice relinquishes, allowing the reader to have access to Hania's thoughts and then to her voice as a storyteller. The overlap between Hania's thoughts and voice and the narrator's voice in FID stands for the translingual shift to the oral represented by the voice of Hania, which intrudes 
the standard French text representing the omniscient narrator's language. To represent the reflecting mind of Hania, pronominal shift, shift in tense, and a set of syntactic expressive features underscore the shift from the narrator's to Hania's perspective. These shifts constitute new syntactical and grammatical structures underscoring the modification of French by Algerian orality represented in the voice of the character focalizer, Hania.

FID marked by shift in pronominal reference, which points to the modification of the grammatical structure of the French text by orality, allows the reader to have a direct access to Hania's troubled consciousness. Thus, we can notice the narrative interrupted by the voice of the character Hania in a first-person reference without any indication to the reader that such a change is about to occur. The reader is, however, allowed a direct access to the thoughts of the character as they unfold. For instance, in "L'insomnie habituelle, se dit-elle, et maintenant, me voici droite sur mes jambes jusqu'à l'aurore !" (2002: 54) [“The usual insomnia, she thought, and now here I am right on my legs until dawn!"], we see no clear boundaries between the direct speech of Hania and its indirect representation. Here, even if the use of "se dit-elle" sets off Hania's thoughts, the text introduces Hania's thoughts without the use of the usual marker of direct speech since these thoughts are neither preceded by dashes nor enclosed in quotation marks. They are, however, marked by a shift in pronominal reference obvious in the use of the first person instead of the third person expected in an indirect discourse representation. Indeed, with the use of "I", we are introduced directly into Hania's mind and thoughts represented in her own voice. The pronominal shift highlights the weariness of the character and incites the reader to think about the causes of this weariness at such an early stage in the novel.

The thoughts unfold to show that Hania's consciousness is troubled by her reluctance to speak with her "visitor" about a harmful past. Therefore, FID marked by syntactic deviations and pragmatic categories - which are also marks of the modification of French by orality - highlights the troubled consciousness of Hania, as the extract below shows:

Comme d'autres fois, Mina reviendra avant la première chaleur éclatée du jour $[. .$.$] .$

Elle rentra avec l'une des fillettes de la maison d'en face, celle qui la suit comme son ombre : Yasmina s'installera dans un coin pour jouer aux osselets (ceux qu'avait dans l'enfance Mina et que Hania lui a conservés). Yasmina demandera à « l'Algéroise »- elle appelle ainsi
As usual, Mina returns before the first bursting heat of the day [...].

She returns with one of the girls of the house across the street; this girl follows her like a shadow: Yasmina stays in a corner to play the dice (those that Mina had in childhood and that Hania has preserved). Yasmina asked "the Algeroise" - as she calls 


\begin{tabular}{|c|c|}
\hline $\begin{array}{l}\text { Mina, ce qui ne plait pas tellement à } \\
\text { Hania - une musique ni traditionnelle, } \\
\text { ni chansonnettes à la mode, 'la } \\
\text { musique', dit-elle, après qu'elle a } \\
\text { entendu une sonate de Mozart, et elles } \\
\text { s'enfermeront dans la pièce d'en haut. } \\
\text { Ainsi, songe Hania, ma sœur, fille } \\
\text { de Zoulikha, l'héroïne de Césarée, } \\
\text { est presque en train de devenir une } \\
\text { femme d'Alger. Ce n'est pas juste ! [...] } \\
\text { Hania, de nuit, de jour, ainsi se } \\
\text { tourmente. [...] Elle espère parfois : Et } \\
\text { si Mina prenait enfin époux? Avec un } \\
\text { époux, pourquoi ne reprendrait-elle } \\
\text { pas sa place, ici, dans la maison de sa } \\
\text { mère? (2002: 54-56) }\end{array}$ & $\begin{array}{l}\text { So, thinks Hania, my sister, Zoulikha's } \\
\text { daughter, the heroine of Cesaree, is } \\
\text { almost becoming a woman of Algiers. } \\
\text { It's not fair! [...]. } \\
\text { Likewise, Hania, night and day, } \\
\text { agonizes. [...]. She sometimes hopes: } \\
\text { if Mina finally chose a husband? With } \\
\text { a husband, why wouldn't she return } \\
\text { here to the house of her mother? }\end{array}$ \\
\hline
\end{tabular}

Many syntactic deviations relate to the deictic centre of the reported consciousness (i.e. Hania's consciousness) and underscore the modification of French by orality. For instance, we notice the alignment of some time and place adverbials to the deictic centre of Hania as in "comme d'autresfois" "la piece d'en haut", "ici, dans la maison de sa mere". These temporal and spatial adverbs indicate a time and a place from Hania's perspective. In some sentences, the representation of Hania's consciousness is rendered through the use of exclamatory constructions and questions, which retain their syntactically direct inverted form representing Hania's words and thoughts. Yet, she is not speaking or thinking them at this moment. It is the narrator who is "listening to them" and using them to translate Hania's thoughts.

Besides these syntactic features of expressivity, some pragmatic categories make the shift, from the reported consciousness to the narrative proper, more explicit. Actually, many typographical features help separate those sentences that relate to the deictic centre of the character from the narrative proper. These include dashes, semicolons, parentheses, and quotation marks. For instance, the dash in "- elle appelle ainsi Mina ..." marks the shift from Hania's perspective to that of the narrator. The parentheses in "(ceux...)" have a similar function. The use of quotation marks with the words "l'Algéroise" and "la musique" mark what Fludernik calls "loanings from the character's lexis" (1993: 227).

Eventually, through its use of FID underscored by shift of pronominal reference, syntactical deviations, and pragmatic categories, the text can weave in and out of Hania's mind. It can glide from narrator to character and back again without perceptible transitions. Two linguistic levels, the character's inner thought and the author's report, are fused into one so that the same current situation seems to pass through narrating and figural consciousness allowing the creation of new grammatical and syntactical structures. The overlap between Hania's thoughts 
and the narrator's voice in FID emphasize the translingual shift to the oral represented by the voice of Hania, which intrudes and changes the standard French text representing the omniscient narrator's language in the passage above.

Djebar finds in FID representing thought an ideal strategy allowing her to create a channel of communication between the narrator and her reluctant informants, who find it difficult to speak about the past whose violence has cut off their voices. Used to represent the thoughts of a character focalizer at an initial stage, FID allows the omniscient narrator to enter the mind of reluctant informants and to represent their thoughts verbatim while allowing them to speak for themselves from within the narration.

To sum up, the translingual shift achieved through FID representing thought generates new grammatical and syntactical structures, which stand as markers of transcultural relations pointing to the modification of French by Algerian orality. Allowing fusion at the linguistic level, FID allows Algerian orality to appropriate, modify, and reinvent French, which turns for the author from an instrument of "oppression", being the colonizer's language, to a viable medium to create connections with her hesitant informants who are allowed to speak in their own accents and idioms.

While using FID to represent thought has made the translingual shift possible as it created chances for a better communication between the narrator-author and the reluctant informants, Djebar experiments further with FID, used to represent voice, achieving further possibilities of switching between languages and further chances of communication and exchange.

\section{FID and the representation of voice}

The shift from the representation of thought to the representation of voice marks the gradual liberation of the character focalizers' voices allowing the gradual disappearance of the narrator's voice. Thus, after being allowed to intrude the narrative through the representation of their thoughts, the character focalizers are allowed further possibilities to speak in narratives where the narrator turns into an attentive "listener." The emergent narratives swing between the representation of voices of two types. One type represents voices haunting the minds of the character focalizers overheard by the narrator. The second type represents voices liberated by immersion in the past and empowered by the active reception of the narrator, who nearly disappears from the text. Djebar uses the narrator to transmit characters' voices rendered in a mix of direct, indirect, and FID, which allows the incorporation of Algerian dialectical morphology, syntax, and lexical peculiarities as well as the modification of the oral.

The narration relies on the power of listening and translating. Djebar's use of FID preserves the sense of listening as the characters' voices are presented as 
being heard. In this context, Djebar's use of FID corresponds to the definition of Gilbert D. Chaitin, who describes FID as a matter of listening and retransmitting; "style indirect libre paved the way for the invasion of narrative [...] by dialogue, the progressive effacement of narrative voice, by making narration a matter of listening rather than speaking, of echoing, receiving and retransmitting” (1999: 1023-1024). Chaitin emphasizes that FID "marks the transformation of the narrator from the traditional authoritative role of the one who knows (the past, the truth, etc.) to the receptive function of the one who listens". The narrator's role in FID is thus not restricted to "simple recording and transmitting; [...] 'it is marked by an active reception of the other speaker's speech" (1999: 1029-1030). The narrator in La Femme is an attentive "listener" who listens patiently and vigilantly so that she could overhear even low and tiny voices still imprisoned in the informants' minds. She is skilful enough to encourage these confined voices to "speak".

\section{Representing overheard voices}

The representation of the voices which haunt the minds of characters relies on the skills of the attentive "listener" who could overhear the haunting voices and then translate them into a language which allows character focalizers to speak from within the narration, resulting in the incorporation of dialect in French and the modification of the oral.

For instance, the narrative in the chapter "Où trouver le corps de ma mère?" ends with the representation of a voice, described as "parole menue, basse" (2002: 63) [a tiny, low voice]. This tiny voice haunts the mind of Hania, rendered in a mix of indirect and FID, marked by the incorporation of some lexical items from Algerian Arabic.

Elle sait. Etre habitée: d'autres femmes, autrefois, disait-on, étaient "peuplées", "habitées" - en arabe, on les surnommait les meskounates -, mais il s'agissait à l'époque d'un djinn, bon ou mauvais esprit avec lequel ces malheureuses devaient composer, ou se soumettre en silence, quelquefois tout au long de leur vie. (2002: 65)
She knows. To be inhabited; in the past, some women, it was said, were "populated", "inhabited" - in Arabic, they were called the meskounates -, but this could mean at that time the existence of a djinn, good or bad spirit with which these unfortunate women were to compromise, or to submit in silence, sometimes throughout all their lives.

Here, the narration is invaded by Algerian lexical items. Djebar represents Hania's silent speech haunting her mind in a manner that fits perfectly well with 
Fludernik's description of how, through FID, an author might provide "the precise flavor of the original utterance or consciousness that is 'true' to a character's mind. One prominent and pervasive manner of doing so is to incorporate lexical items from the character's or reported speaker's idiolect, sociolect, dialect or (foreign) language" (1993: 255). Djebar represents what is true to Hania's mind by incorporating lexical items from her idiolect (Algerian Arabic). Many lexical peculiarities are clearly part of Hania's private language as "peuplées" "habitées" which are literal translations from Algerian Arabic to French of the lexical item "meskounates", transposed from Algerian Arabic, meaning 'haunted'. The word "habitée”, meaning 'haunted', recurs many times in the novel but with opposing connotations.

It is used to convey the negative connotations of being haunted by a djinn or a ghost, which in the past frightened women and silenced them. This word is used in the passage above reflecting Hania's consciousness, who in another passage claims with some anxiety in direct speech "j'en suis habitéé" (2002: 92; my emphasis) 'I am inhabited', meaning that she is haunted. In these two occurrences, "habitée" bears the same negative connotations as the transposed word "mekounates" suggests. Being "habitée" frightens Hania and reduces her voice to silence just as it used to frighten and silence the unfortunate women called "meskounates".

"Habitée" is later used as an equivalent of being haunted but with positive connotations. It is used in an indirect speech passage by the narrator-author, who appears with a first-person voice marking an abrupt authorial intrusion in the middle of the novel. This authorial voice claims with comfort: "je raconte ma nuit, habitée encore par ces récits de Zoulikha” (2002: 123; my emphasis) 'I recount my night, still inhabited by narratives about Zoulikha'. "Habitée” is also used in a narrative focalized by the narrator, who adopts a particularly colloquial and even dialectal style, suggesting the merging of the voice of narrator with the voices of characters, "Tandis que Mina, [...] conduit en silence, son amie qu'on peut supposer somnolente, mais en réalité habitée entièrement par les derniers récits de la veille" (2002: 164; my emphasis) 'While Mina [...], drives in silence, her friend seems sleepy, but in reality she was entirely inhabited by the latest narratives of the day'. The lexical item is later used in a passage focalized by Mina, "puisque cette femme reste ainsi habitée par l'histoire de Zoulikha, pourquoi, dès lors, sa hâte soudaine à partir?" (2002: 165; my emphasis) 'Since this woman is still inhabited by the story of Zoulikha, why, then, this sudden rush to leave?' After the authorial intrusion to modify the meaning of "habitée", both narratorial and character's - Mina's - voices seem satisfied with the emergent new meaning, which is suggested through the repetition of a lexical item with similar positive connotations.

After the negotiation of its meaning, "habitée" is liberated of negative connotations. It acquires new positive connotations for women of postcolonial Algeria, represented by the narrator author and Zoulikha's daughters. Djebar 
asserts the legitimacy of being haunted, or "habitée", by voices, and she repeats and reverses all the negative connotations that tradition has associated with it. To be haunted, or "habitée", the equivalent of "meskounates" in tradition, does not frighten the narrator-author and her friend Mina, and even less Hania, who, at the end of the novel, seems less anxious about being "habitée", as a consequence of liberating the voice which haunts her. Liberating the lexical item from negative connotations through an act of translation relying on negotiating meanings across languages and across cultures allows the oral to acquire new meanings. From "meskounates" to "habitée", to the legitimacy of being haunted suggested through the recurrence of the word "habitée" with positive connotations, new meanings emerge. A fundamental emergent meaning is emphasis on the legitimacy for women to speak their minds against the silence imposed by such traditional irrational taboos as those embedded in "meskounates" or being haunted, or "habitée" by a djinn.

Allowing the Arabic lexical item to acquire new meanings through contact with French is reciprocal to the liberation of women's voices. French language has been appropriated and reinvented to vibrate with Algerian orality, which has also acquired new meanings as the "haunting" metaphor shows. ${ }^{3}$ The new meanings could liberate women's voices, which - as Hania's voice - have been tiny and low ("parole menue, basse") but which could gradually get liberated through negotiating meanings cross-linguistically and cross-culturally. The liberation of the oral through contact with French underlines the potentialities of choosing translingual practices to write the oral, of choosing a French text to recover the silenced oral voices.

While the use of FID has allowed the liberation of the oral through the negotiation of meanings across languages and across cultures, FID has also been used to represent "speaking" oral voices offering further possibilities of mutual influence between languages and further chances for transcultural connection and exchange.

\section{Representing "speaking” voices}

In texts presented as oral narratives, separated from written discourse by the heading "voice of ..." followed by the name of a character focalizer approximate to a storyteller, the translingual shift is achieved through a FID marked by the doubling of voices. Here, the narrator's voice intrudes the oral narrative in the voice of the storyteller emphasizing the modification of the oral.

The example I propose to illustrate the translingual transformations with in oral narratives is a narrative told by Zohra Oudai. In the extract below, the

3 The lexical item "habitée" recurs in another novel with the new emergent meaning and the claim for voice against silence. See Le Blanc de L’Algérie, p. 56. 
reader discovers Zohra as an excellent translingual storyteller, who could switch between languages, Arabic, Berber, and even French, which merge harmoniously in her oral narrative.

A cette époque-là, Zoulikha restait
souvent avec moi au refuge.
(Ce mot « refuge » est prononcé à la
Française, mot étrange au milieu de ce
parler en arabe populaire, gauchi par
un accent particulier aux gens de ces
montagnes plutôt berberophones. [...])

Quand le commissaire politique (encore deux mots en français !) survenait, il notait par écrit tout ce que Zoulikha apportait. Ils écrivaient [...] ici même, sur ma meida : cette table, si elle avait une âme, comme elle aurait parlé !..."

(2002: 82-83; last ellipsis in the original)

While the two parenthetical comments of the narrative commentary underscore the storyteller's ease in alternating between languages, the oral narrative of the extract offers excellent examples of switching languages. Importantly, Zohra's translingual shift apparent in the use of French words "refuge" "commissaire politique" pronounced with specific intonational markers underscore the modification of the oral, which generates new lexical structures. Additionally, the FID sentence "ici même, ... parlé !...” marked by the doubling of voices - the voice of the storyteller and that of the narrator - offers other significant instances of Djebar's translingual practices. In this sentence, the narrator intrudes Zohra's narrative to transpose, then retranslate the lexical item meida (the Algerian word for a short-legged table with multiple uses). The Arabic lexical item is transposed in French, then retranslated into "cette table" as a substitute for the earlier translation "cette table basse" in an earlier narrative told by Zohra:

\footnotetext{
"Si cette table basse pouvait parler... "If this coffee table could speak ... Elle est le seul souvenir qu'il me reste It is the only memorial left of my de ma demeure incendiée. (Après un burnt house. (After some time:) When silence :) Quand Zoulikha venait au Zoulikha came to the village, she douar, elle apportait les médicaments, used to bring medicines, she brought elle apportait la poudre, elle apportait powder, she brought money! ..." l'argent !..." (2002: 80; ellipsis in the original)
} 
Through this two-way translingual shift, characterized by movement between French and Algerian orality achieved through translating, transposing, and retranslating, better chances of communication are created. In the above extract, the cultural item "cette table basse" is a reminder of a burnt house and colonial violence in a translation focused on preserving the purity of the French language. As a consequence, Zohra's voice is hesitating, reluctant, and interrupted by silences, suggesting the impossibility of the recuperation of the forgotten and the impossibility of communication between the women who lived through the colonial turmoil - Zohra - and the women of postcolonial Algeria - the visitor collecting history. In the second translation, through the two-way translingual shift in "ma meida: cette table", the lexical item acquires a different function. It helps the storyteller to recover and reconcile with the past, and the translingual speaker is a happier storyteller as she could overcome both colonial violence and the deceptiveness of the present to focus on the recuperation of key moments of this past. This was a time when gender boundaries were dislocated, when both women and men were equally actively engaged in the decolonization struggle as suggested through the image of "le commissaire politique" writing down over "ma meida", what Zoulikha has brought. The politician registers the contribution of the female freedom fighter to the revolutionary struggle over the multi-tasking translingual meida-table which survived colonial violence.

Here, we may also emphasize that Djebar's translingual practices in oral narratives seem to reflect upon the switching of languages common in Algerian oral languages. Indeed, after contact with French due to the colonial presence in Algeria, many French words have been incorporated in the oral languages. These words are being used with special intonational peculiarities. One of these words is the word "table", which was incorporated in Algerian orality as another alternative for "meida", which is an appropriation from literary Arabic, yet pronounced with specific intonation. Two words travelling from two different languages to translate the same item for a people who might have lost their mother tongue word for this item. Yet, they appropriated two words and two languages to create new words so that they could communicate across languages and across cultures. To sum up, the two-way translingual shift achieved through FID representing voice generates new lexical structures and new meanings, which promote transcultural relations.

\section{Conclusions}

To conclude, the in-depth analysis of the use of language in one of Djebar's novels, focused on demonstrating the mutual influence between Algerian orality and French, has enabled us to explore linguistic as well as cultural transformations resulting from historical changes. Some major findings emerged out of this study. 
First, contact between orality and French results in new meanings, new grammatical, syntactical, and lexical structures which underscore the mutual influence between the languages in contact. Selected passages from the novel under scrutiny show that French is modified by Algerian orality, which is equally modified by French. The texts achieve this mutual influence through a mix between direct, indirect, and free indirect discourses. FID allows the overlap between characters' and narrator's voices, allowing Algerian orality imbedded in characters' voices to modify the narrator's French while being modified by it. Such modifications noticed in the selected passages include the shift of pronominal reference, syntactical deviations, and the use of special typographical features in addition to the incorporation of Arabic lexical items.

Second, through this attempt to demonstrate the mutual influence between orality and French in a sample novel, the transformations evident in the text can be interpreted as justifying translingual rather than multilingual practices. Even if the generalization of such finding requires the examination of Djebar's other work, it is perhaps possible to say that the Arabic lexical items and the syntactic structures in Djebar's work can aim to achieve deeper relations than those achieved through multilingual practices. The latter treat languages additively as a "combination of separate languages", allowing no synergy between the layers of a resulting "palimpsest". Therefore, interpreting the presence of Arabic in Djebar's novels as structures added in Djebar's text to "deterritorialize" or to "reterritorialize" French oversimplifies the relation between orality and French in Djebar's work.

Third, reinvented through translingual practices relying on the mutual influence between languages, Djebar's French is sufficiently modified to promote transcultural connections. The latter are viable to promote communication in a postcolonial Algeria reduced to violence as a consequence of the language policies imposing linguistic purity on past and present. Such language policies cut all channels of communication between Algerians instructed towards a preference for Arabic, those who overemphasize the 'civilizing' value of French and those who want to reinvent a long-neglected Berber mother tongue.

Against homogeneity and linguistic purity, Djebar proposes the contact among "three languages" to write Algeria. Consequently, Djebar's choice to use a language which switches between "three languages" to resuscitate female voices and recover the past finds an adequate justification. Neither the language imposed by the colonizer nor the language imposed by the postcolonial leadership, not even the long-neglected Berber language could resuscitate those voices that have ever communicated through strategic negotiations across languages. Such a choice allows for the creation of cross-cultural commonalities that discourses of homogeneity and exclusion have always tried to crash and silence. To achieve her project of resuscitating the past and the female voice, 
Djebar chooses a qalam, which, although held by "a hand of mutilation" (1993: 226) offered by the colonizer, is not bound by linguistic purity requirements. Djebar's linguistic choice creates channels of communication and coexistence to overcome homogeneity and exclusion using a three-lingual translingual qalam to write Algeria and its women.

\section{References}

Canagarajah, Suresh. 2013. Negotiating translingual literacy: An enactment. Research in the Teaching of English 48(1): 40-67.

- 2017. Translingual Practices and Neoliberal Policies Attitudes and Strategies of African Skilled Migrants in Anglophone Workplaces. Switzerland: Springer.

Chaitin, Gilbert D. 1999. Listening power: Flaubert, Zola, and the politics of style indirect libre. The French Review 72(6): 1023-1037.

Djebar, Assia. 1988. Entretien avec Assia Djebar, Ecrivain Algérien by Mildred Mortimer. [Interview with Assia Djebar, Algerian writer]. Research in African Literatures 19(2): 197-205.

1993. Fantasia an Algerian Cavalcade. Transl. Dorothy S. Blair. Portsmouth, NH: Heinemann.

1995. Le Blanc de L'Algérie [The White of Algeria]. Paris: Albin Michel.

2002. La Femme sans sépulture [The Woman without Sepulchre]. Paris: Albin Michel.

2003. Writing in the language of the other. In Isabelle De Courtivron (ed.), Lives in Translation: Bilingual Writers on Identity and Creativity, 19-27. New York: Palgrave Macmillan.

Donadey, Anne. 2000. The multilingual strategies of postcolonial literature: Assia Djebar's Algerian palimpsest. World Literature Today 74(1): 27-36.

Fludernik, Monika. 1993. The Fictions of Language and the Languages of Fiction. The Linguistic Representation of Speech and Consciousness. London and New York: Routledge.

Liu, Lydia H. 1995. Translingual Practice. Literature, National Culture, and Translated Modernity - China 1900-1937. Stanford: Stanford UP.

O'Riley, Michael F. 2007. Postcolonial Haunting and Victimization: Assia Djebar's New Novels. New York: Peter Lang.

Rosello, Mireille. 2005. France and the Maghreb: Performative Encounters. Gainesville: UP of Florida.

Tageldin, Shaden M. 2009. Which qalam for Algeria? Colonialism, liberation, and language in Djebar's L'Amour, la fantasia and Mustaghānimī's Dhākirat Al-Jasad. Comparative Literature Studies 46(3): 467-497 
Welsch, Wolfgang. 2009. On the acquisition and possession of commonalities. In Frank Schulze-Engler and Sissy Helff (eds), Transcultural English Studies, Theories, Fictions, Realities, 3-36. Amsterdam, New York: Rodopi.

Welsch, Wolfgang. 1999. Transculturality: The puzzling form of cultures today. In Mike Featherstone and Scott Lash (eds), Spaces of Culture: City, Nation, World, 194-213. London: Sage. 